\title{
Seroprevalence for dengue virus in a hyperendemic area and associated socioeconomic and demographic factors using a cross-sectional design and a geostatistical approach, state of São Paulo, Brazil
}

Francisco Chiaravalloti-Neto ${ }^{1 *}$ (D, Rafael Alves da Silva ${ }^{2}$, Nathalia Zini ${ }^{2}$, Gislaine Celestino Dutra da Silva ${ }^{2}$, Natal Santos da Silva ${ }^{3}$, Maisa Carla Pereira Parra ${ }^{2}$, Margareth Regina Dibo ${ }^{4}$, Cassia Fernanda Estofolete ${ }^{2}$, Eliane Aparecida Fávaro ${ }^{2}$, Karina Rocha Dutra ${ }^{2}$, Manlio Tasso Oliveira Mota², Georgia Freitas Guimarães², Ana Carolina Bernardes Terzian², Marta Blangiardo ${ }^{5}$ and Mauricio Lacerda Nogueira ${ }^{2}$

\begin{abstract}
Background: São José do Rio Preto is one of the cities of the state of São Paulo, Brazil, that is hyperendemic for dengue, with the presence of the four dengue serotypes.

Objectives: to calculate dengue seroprevalence in a neighbourhood of São José do Rio Preto and identify if socioeconomic and demographic covariates are associated with dengue seropositivity.

Methods: A cohort study to evaluate dengue seroprevalence and incidence and associated factors on people aged 10 years or older, was assembled in Vila Toninho neighbourhood, São José do Rio Preto. The participant enrolment occurred from October 2015 to March 2016 (the first wave of the cohort study), when blood samples were collected for serological test (ELISA IgG anti-DENV) and questionnaires were administrated on socio-demographic variables. We evaluated the data collected in this first wave using a cross-sectional design. We considered seropositive the participants that were positive in the serological test (seronegative otherwise). We modelled the seroprevalence with a logistic regression in a geostatistical approach. The Bayesian inference was made using integrated nested Laplace approximations (INLA) coupled with the Stochastic Partial Differential Equation method (SPDE).

Results: We found 986 seropositive individuals for DENV in 1322 individuals surveyed in the study area in the first wave of the cohort study, corresponding to a seroprevalence of $74.6 \%$ (95\% Cl: $72.2-76.9)$. Between the population that said never had dengue fever, 68.4\% (566/828) were dengue seropositive. Older people, non-white and living in a house (instead of in an apartment), were positively associated with dengue seropositivity. We adjusted for the other socioeconomic and demographic covariates, and accounted for residual spatial dependence between observations, which was found to present up to $800 \mathrm{~m}$.

(Continued on next page)
\end{abstract}

\footnotetext{
* Correspondence: franciscochiara@usp.br

'Departamento de Epidemiologia, Faculdade de Saúde Pública, Universidade

de São Paulo (USP), Avenida Doutor Arnaldo 715, São Paulo, SP 01246-904,

Brazil

Full list of author information is available at the end of the article
}

(c) The Author(s). 2019 Open Access This article is distributed under the terms of the Creative Commons Attribution 4.0 International License (http://creativecommons.org/licenses/by/4.0/), which permits unrestricted use, distribution, and reproduction in any medium, provided you give appropriate credit to the original author(s) and the source, provide a link to the Creative Commons license, and indicate if changes were made. The Creative Commons Public Domain Dedication waiver (http://creativecommons.org/publicdomain/zero/1.0/) applies to the data made available in this article, unless otherwise stated. 
(Continued from previous page)

Conclusions: Only one in four people aged 10 years or older did not have contact with any of the serotypes of dengue virus in Vila Toninho neighbourhood in São José do Rio Preto. Age, race and type of house were associated with the occurrence of the disease. The use of INLA in a geostatistical approach in a Bayesian context allowed us to take into account the spatial dependence between the observations and identify the associated covariates to dengue seroprevalence.

Keywords: Dengue, Seroprevalence, Cross-sectional study, Geostatiscal analysis, Brazil

\section{Background}

Dengue (DENV) is an arbovirus transmitted by hematophagous mosquitoes of Aedes genus, mainly Aedes aegypti, and presents four serotypes: DENV-1to 4. The disease caused by DENV is considered an important world public health problem, mainly in tropical and subtropical regions, both in terms of morbidity and mortality and is endemic in more than 125 countries. Estimates point out a world incidence around 80 million cases for 2015, amount 2.5 times the incidence estimated for 2005, and 10,000 deaths per year [1-6]. Brazil presented in recent years a sharp increase in dengue incidence and number of deaths, a picture related to the multiple viral circulation, and accounts for around $70 \%$ of the dengue cases in Americas [7].

The development of studies to identify the determinants of DENV infection is of fundamental importance for the definition of preventive measures and for the structuring of adequate surveillance systems and effective control programs [8]. However, most of them are based on information obtained from the reporting systems which are based on cases confirmed by laboratory and clinical-epidemiological criteria $[9,10]$. This causes important limitations for these type of studies, since they are based on symptomatic cases, are subject to underreporting and do not take into account that a large proportion of dengue infections are asymptomatic [9, 11-14].

Instead, seroepidemiological studies are not subjected to the limitations of the investigations based on incidence data reporting systems and provide a more realistic picture of the disease burden in the population. In addition, they are considered useful for evaluating the effectiveness of control measures, including the establishment of vaccination strategies and evaluation of their effectiveness [9, 14, 15]. Recently a dengue vaccine has been licensed in some countries in Latin America and Asia with the recommendation to be used only in endemic and high seroprevalence regions for dengue [16]. In countries where this strategy is being or will be considered, the development of seroepidemiological studies are or will be fundamental for the definition of the regions and population groups to be vaccinated.
Despite their importance, Imai et al. [9] report the relative rarity of seroepidemiological studies compared to the volume of studies based on data provided by surveillance systems. A fact that can be attributed to the limited resources for their development in countries where dengue is endemic [17]. The picture is not different in Brazil and in the state of São Paulo. According to the literature review we conducted in scientific journals, we identified in Brazil, eight seroepidemiological studies conducted in the 1990s [11, 18-24], seven in the 2000s [25-31] and only three in the 2010s [32-34]. From these study, only three were developed in the state of São Paulo, all of them in the 1990s [21-23].

Considering the rarity of this type of study in Brazil, especially in the 2010s, and on the other hand, its epidemiological importance, we highlight the present seroprevalence study carried out in the state of São Paulo. It was developed, as part of a dengue prospective cohort study, to calculate the seroprevalence of dengue in a neighbourhood of the municipality of São José do Rio Preto and to identify if socioeconomic and demographic covariates are associated with the dengue seropositivy.

\section{Methods}

\section{Study area, type and period}

The study was developed in the municipality of São José do Rio Preto, state of São Paulo, Brazil (Fig. 1). The city is located in the country's southwestern region in latitude $20^{\circ} 49^{\prime} 11$ 'S and longitude $49^{\circ} 22^{\prime} 46^{\prime \prime} \mathrm{W}$, has a population of around 450,000 inhabitants, tropical climate with temperature and average annual rainfall of $25^{\circ} \mathrm{C}$ and $1410 \mathrm{~mm}$, respectively, and altitude of $475 \mathrm{~m}$ asl. The HDI (Human Development Index) of São José do Rio Preto is 0.797, one of the highest in Brazil (52th position among the 5565 Brazilian municipalities) (www.ibge.gov.br).

We selected, as the study area, an area belonging to Vila Toninho neighborhood located in the southeastern part of the urban part of the city (Fig. 1b), with 5575 inhabitants, 4809 with 10 years or older (2322 male and 2487 female), 1937 residences and 4806 inhabitants per $\mathrm{km}^{2}$. Vila Toninho is located in the outskirts of São José do Rio Preto and has socioeconomic indicators worse than the city averages: $87.9 \%$ of people with five or more 

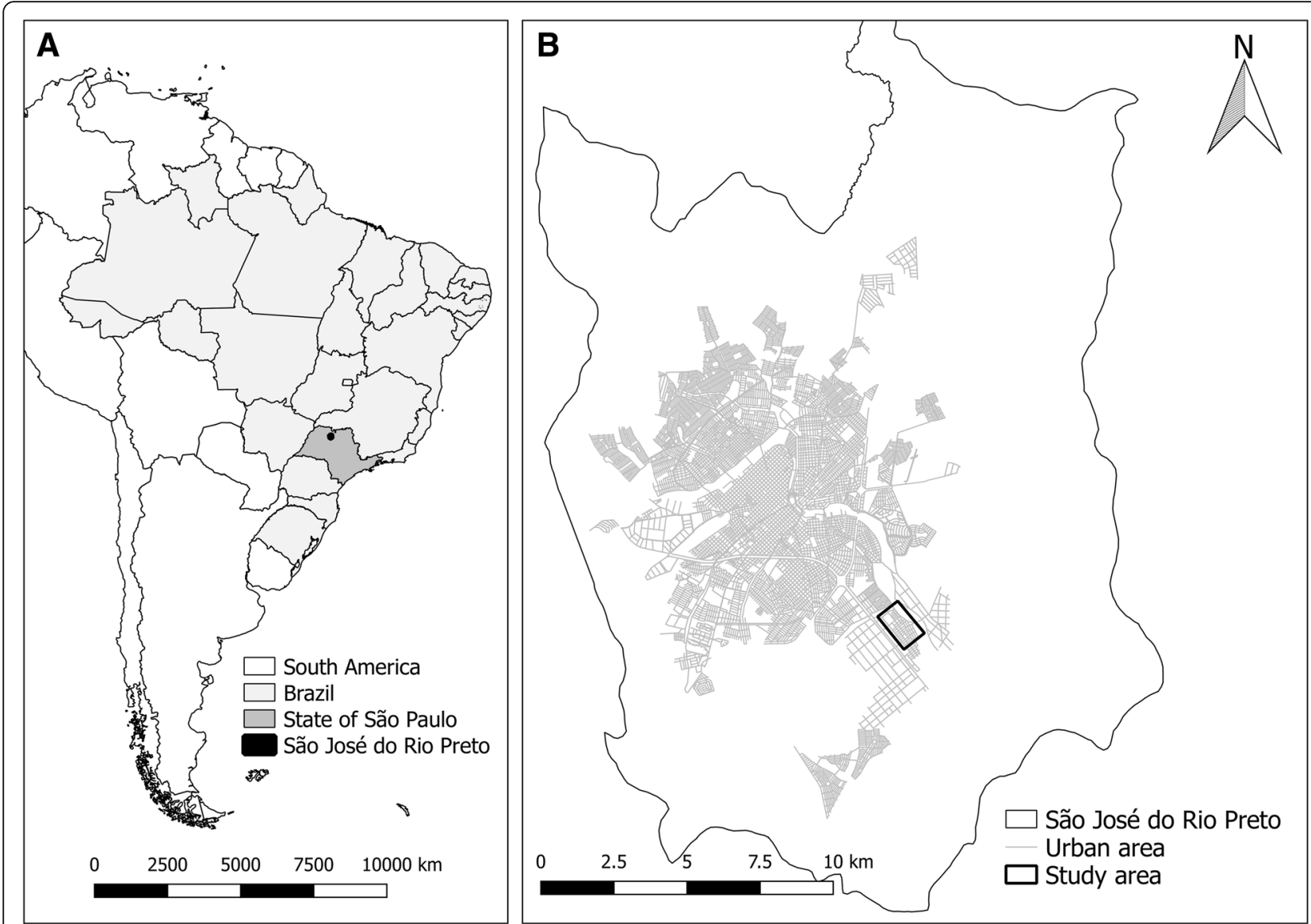

Fig. 1 a: Municipality of São José do Rio Preto, state of São Paulo, Brazil, South America; b: Vila Toninho neighborhood (study area) in the municipality of São José do Rio Preto

years are literate, average income of head of household of 1.9 Brazilian minimum salaries (MS) and $15.3 \%$ of the household with five or more residents (against, respectively, 95.9\%, $5.7 \mathrm{MS}$ and $11.5 \%$ for the entire municipality) (www.ibge.gov.br).

The reinfestation by Ae. aegypti in São José do Rio Preto was detected in 1985 (Chiaravalloti-Neto 1997), the first autochthonous cases by DENV-1 occurred in 1990 and the first dengue epidemic occurred on 1994-1995. DENV-2, DENV-3 and DENV-4 were detected, respectively in 1998, 2005 and 2011, causing new epidemics, so that the city is considered hyperendemic for dengue fever $[35,36]$. In the 2010s, three major dengue epidemics occurred in the city: 25 thousand cases in 2010, 19 thousand in 2013 e 22 thousand in 2015. Even though these epidemics have reached all over the city, one of their characteristics has been present higher incidences in the most peripheral and the poorest area of São José do Rio Preto, including Vila Toninho neighbohood. Taking this in account, we chose this neighbourhood as study area because it well represents the most susceptible regions of the city for the occurrence of dengue $[35,37,38]$.
A cohort to investigate dengue seroprevalence and seroincidence and associated factors was assembled in the study area and the participants were enrolled between October 2015 and March 2016 (the cohort first wave). Besides the first wave, the cohort includes more three waves to measure the seroincidences (one measure per year). The present study is a cross-sectional analysis of the data collected during the cohort first wave.

\section{Study population}

The eligibility criteria to participate of the cohort were to be 10 years or older and to be a resident of Vila Toninho neighbourhood. To obtain the sample size necessary for the development of the study, we estimated that 380 seronegative individuals would be necessary to measure a seroincidence of $10 \%$, with an error margin of $3 \%$ and a significance level of $5 \%$, by the fourth and final wave of the cohort. We established the initial sample initial size around 1400 individuals considering that we would also have seroincidences of $10 \%$ and annual losses of $10 \%$ in the first, second and third waves of the cohort and a seroprevalence of $50 \%$ in the first wave. 


\section{Data collection}

We visited all households in the study area and, in those that were not closed during our visits, all residents aged 10 years or older were invited to participate in the cohort. After agreement and signature of the Informed Consent Form, the study participant answered a structured questionnaire about their sociodemographic characteristics and past dengue occurrence. The questionnaire also included questions on the knowledge of the disease, vector and control measures, issues to be addressed in future publications. Two blood tubes were then collected from the participant, one for the collection of whole blood (with K2 EDTA $7.2 \mathrm{mg}$ anticoagulant (BD Vacutainer $\left.{ }^{\circ}\right)$ ) and another to obtain serum (SST ${ }^{\mathrm{max}}$ BD Vacutainer tubes). The tubes were sent under refrigeration to the Laboratory of Virology of School of Medicine of São José do Rio Preto (FAMERP), centrifuged at a rate of $2000 \mathrm{~g}$ for $10 \mathrm{~min}$ and stored in a freezer at $-80^{\circ} \mathrm{C}$ until. The period we made these blood collections was before the Zika virus circulation in the city.

Serum exams of the study participants were performed using the anti-DENV IgG ELISA method, using the commercial kit Human Anti-Dengue vírus IgG ELISA kit (Abcam ${ }^{\circ}$, Cambridge, United Kingdom) and following the manufacturer's instructions. The optical density (OD) reading was performed at an absorbance of 450 $\mathrm{nm}$ with the equipment Spectramax Plus ELISA reader (Molecular Devices $\odot$ ) and the calculations were made according to the kit instructions.

The residential addresses of the individuals enrolled in the study were geocoded using a georeferenced street map that was available by the São José do Rio Preto City Council. Then, for each enrolled individual we obtained their plain Cartesian coordinates in meters in the UTM coordinate system, 22S zone, Datum SIRGAS 2000. We attributed a code for each participant and its collected data (questionnaire, serological test result and Cartesian coordinates) were typed in a Microsoft Excel spreadsheet.

\section{Variables}

The study dependent variable was the seropositivity for dengue (IgG). We considered as seropositive (IgG pos), a participant who presented a positive test for dengue in the anti-DENV IgG ELISA serological test and seronegative (IgG neg), otherwise. We considered the following categorical covariates as predictors: sex (male or female), race (white or non-white), marital status (not married or married), occupation (inside or outside); schooling $(<=7$ or $>7$ years), house type (apartment or house), home ownership (owner or non-owner), hours at home $(<=12 \mathrm{~h}$ or $>12 \mathrm{~h}$ per day) and number of residents $(<=4$ or $>4$ residents in the house). We also considered the standardized continuous covariates age and income as predictors. The standardization consisted in subtracting from the values of these covariates the respective means, followed by the division by the respective standard deviations.

\section{Statistical analysis}

We used dot plot charts to identify possible outliers, calculated the percentage of missing data for each variable and evaluated the collinearity between predictors using the variance inflation factor (VIF), using a threshold equal to 3 [39]. As we had missing data in several covariates, we used the multivariate imputation by chained equation methods for the imputation, under the assumption that the missingness occurred at random [40]. For the imputation we used R Statistical software [41] and the mice package [40].

To model the dengue seropositivity (IgG) we specified a Bernoulli probability distribution (eqs. 1 and 2) in a Bayesian context:

$$
\begin{aligned}
& \operatorname{Ig} G_{i} \sim \operatorname{Bern}\left(\pi_{i}\right) \\
& \operatorname{logit}\left(\pi_{i}\right)=\alpha+\sum_{p=1}^{p} \beta_{p} X_{p i}+W\left(\boldsymbol{s}_{i}\right)
\end{aligned}
$$

where $\mathrm{i}=1, \ldots, \mathrm{N}$ represents the ID of a particular individual; $\pi_{i}$ is the probability of a individual to be dengue seropositive; $\alpha$ is the intercept; $\boldsymbol{\beta}$ is the vector of $\mathrm{P}$ regression parameters for the predictors; $\mathbf{X}$ is the matrix of predictors. Finally, $\mathbf{s}_{\mathbf{i}}$ are the Cartesian coordinates of the individual residential location and $\mathrm{W}\left(\mathrm{s}_{\mathrm{i}}\right)$ is a realization of a latent stationary Gaussian field (GF) that models the spatial dependence between the address locations of the participants (Cartesian coordinates):

$$
\mathbf{W} \sim \operatorname{MVN}(0, \boldsymbol{\Sigma})
$$

We modelled the spatially structured covariance matrix $\Sigma$ by a Matérn function [42] (Cressie 1993), considering the Euclidean distance between the individual locations. The GF was represented by a Gaussian Markov random field (GMRF) and we applied the Integrated Nested Laplace Approximations (INLA) approach [43] and coupled with the stochastic partial differential equation (SPDE) for Bayesian inference using the R statistical software [41] and R-INLA package (www.r-inla.org).

We ran the following models: (i) including only the intercept (intercept non-spatial model); (ii) including the intercept and the spatial component (intercept spatial model); (iii) including the intercept and covariates for the non-imputed dataset (complete covariate non-spatial model); (iv) including the intercept, covariates and the spatial component for the non-imputed dataset (complete covariate spatial model); (v) including the intercept and covariates for the imputed dataset (imputed covariate non-spatial model); (vi) including the intercept, covariates and the spatial component for the imputed dataset 
(imputed covariate spatial model). The process to impute the missing data [40] is the following:

1) We use the mice package to regress each variable (with missing) against all the others and obtain five imputed datasets. This was based on Rubin [44], who concluded that $m$ equal to five would be sufficient for multivariate imputation.

2) For each imputed dataset we ran model (v) and (vi) described above and obtained the regression coefficients (betas) and their respective standard errors for each one of the covariates.

3) We use Rubin's rules [44] for combining the estimates into the final ones. This process is explained, in more details, in the Additional file 1.

We ran the six models and used the Deviance Information Criteria (DIC) [45] to compare their goodness of fit. Based on this, in the results we focused on the imputed covariate spatial model (model vi) which was characterised by the lowest DIC (corresponding to the best fit); the other models are presented as Additional Materials. After, running model vi without considering interactive effects, we investigated these effects considering all possible interactions among the covariates that were associated with a positive serological result for dengue.

We present the posterior means of the fixed effects and $95 \%$ credible intervals (CI) in the logit scale (betas), for models (v) and (vi), and in natural scale (odds ratio (OR)), for model (vi). As this is the first study of dengue seroprevalence in São José do Rio Preto and we did not have prior knowledge about the relationship between the seroprevalence and the covariates, we assumed non-informative priors for the fixed effects in all models and penalized complexity (PC) priors (weak informative priors) for the spatial random effects in the spatial models [46]. The codes for running models (v) and (vi) are presented in Additional file 2.

\section{Results}

When we concluded the data collection for the first wave of the cohort study, we obtained blood samples for 1347 individual; in Fig. 2 we show the distribution of the IgG test results for dengue across the cohort. Out of 1347 individuals, 25 had inconclusive IgG results for dengue. Thus, we considered in this analysis, 1322 individuals with conclusive IgG results for dengue and geocoded address locations. 986 had positive IgG for dengue, resulting in a seropositivity for dengue of $74.6 \%$ (95\% CI: 72.2-76.9).

Table 1 presents the distribution of dengue seropositivity across the 1322 individuals (with a conclusive result) split by the covariates included in the statistical model; some of these presented missing data (NA), and in particular income and race had, respectively, 15.3 and $8.1 \%$ of NA answers, while the other remaining covariates presented a proportion of missing data lower than $4.0 \%$. We did not identify outliers and collinearity between the covariates. The VIF value considering all covariates was 1.8 (below the chosen threshold). The age and income are presented as categorical in Table 1 and income was categorized in MS.

Table 1 also presents the distribution of cohort sample, among which we highlight that it was composed mainly by people of female sex (60.6\%), aged between 20 and 59 years old (68.1\%), whites (51.4\%), married (56.4\%), with income less than $4 \mathrm{MS}$ (76.9\%), living in houses (83.6\%) and only $7.2 \%$ with more than 12 years of schooling (upper secondary level of education). Our study also showed that $62.6 \%(828 / 1322)$ of our study population said that never had dengue fever, but among these, 68.4\% (566/828) were dengue seropositive.

Our final model, with intercept, covariates and the spatial component for the imputed datasets, is presented in Table 2. Age, race and house type were positively associated with a positive serological result for dengue, after adjustment for socioeconomic and demographic covariates considered in our study and for the spatial dependence between the observations. The combination of the separate estimates that produced these results is presented in Additional file 1. Table 2 also presents the crude OR for the imputed covariate spatial model. The main difference between the crude and adjusted OR is the lack of importance of the covariate Occupation in the final model.

The investigation of interactive effects in our final model showed that the best fitted model was the one without any interactions (lowest DIC). Also, all the CI 95\% for the OR of the interaction terms tested included the unit. We present the DIC values for all fitted models in Additional file 3, where is also possible to see that the models with spatial component presented lower DIC than those without this component and showed better goodness of fit.

The spatial correlation of the models we run for the five imputed databases showed that the maximum distances to where the spatial dependence was present ranged from 848.1 to $919.9 \mathrm{~m}$. The median was $866.1 \mathrm{~m}$ and corresponded to the first imputed database; then we show its spatial structure. We obtained a range of around $1000 \mathrm{~m}$ for the intercept spatial model (i.e., the spatial model without the covariates), showing that only part of the spatial dependence present in the data was explained by the considered covariates.

Figures 3 and 4 present, for the model we run for the first imputed database, respectively, the posterior mean of the spatial random field in the study area and the posterior mean of the spatial random field for the location 


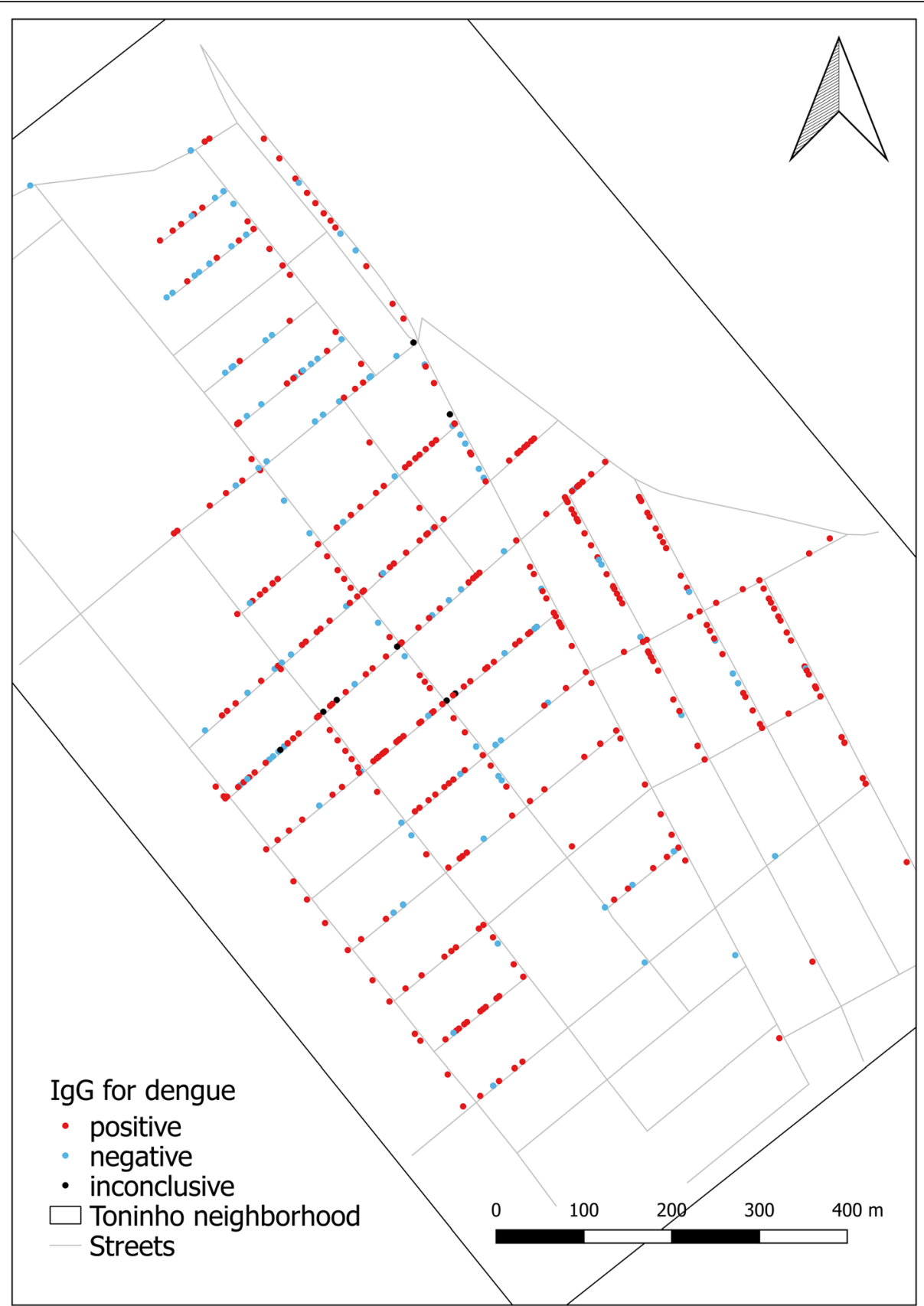

Fig. 2 Vila Toninho neighborhood and the distribution of seropositive, seronegative and inconclusive dengue cases, São José do Rio Preto, State of São Paulo, Brazil, 2015-2016

of the positive and negative dengue cases. These two figures show that the distribution of the spatial random field is not uniform and needs to be considered. In the areas localized in the north-western and western parts of Vila Toninho neighbourhood, the spatial random effect, adjusted for the socioeconomic and demographic covariates, is negative which points towards a reduced probability of occurrence for dengue; in the other areas of the Vila Toninho neighbourhood (excluding that with spatial random effect equal to zero), the spatial random effect, adjust for the same covariates, is positive, meaning that the probability of dengue seropositivity is higher in those areas.

Additional file 4 presents the results of the complete covariate spatial model compared with those of the final model. As the first model was run considering only the individuals with complete data, the sample size diminished to 958, with a loss of $27.5 \%$. The fixed effects of 
Table 1 Dengue lgG seropositivy by covariates, considering the missing data (NA), Vila Toninho neighborhood, São José do Rio Preto, state of São Paulo, Br, 2015-2016

\begin{tabular}{|c|c|c|c|c|c|c|c|}
\hline \multirow[t]{2}{*}{ Covariate } & \multirow[t]{2}{*}{ Category } & \multicolumn{2}{|c|}{ lgG neg } & \multicolumn{2}{|c|}{$\operatorname{lgG}$ pos } & \multicolumn{2}{|c|}{ Total (1322; 100\%) } \\
\hline & & $n$ & $\%^{\mathrm{a}}$ & $n$ & $\%^{\mathrm{a}}$ & $n$ & $\%^{\mathrm{b}}$ \\
\hline \multirow[t]{2}{*}{ Sex } & Male & 130 & 25.0 & 391 & 75.0 & 521 & 39.4 \\
\hline & Female & 206 & 25.7 & 595 & 74.3 & 801 & 60.6 \\
\hline \multirow[t]{4}{*}{ Race } & White & 197 & 29.0 & 482 & 71.0 & 679 & 51.4 \\
\hline & Black and mixed & 105 & 21.6 & 381 & 78.4 & 486 & 36.8 \\
\hline & Others & 11 & 22.4 & 38 & 75.6 & 49 & 3.7 \\
\hline & NA & 23 & 21.3 & 85 & 78.7 & 108 & 8.1 \\
\hline \multirow[t]{4}{*}{ Age (years) } & 10 to 19 & 72 & 36.9 & 123 & 63.1 & 195 & 14.7 \\
\hline & 20 to 39 & 120 & 26.3 & 337 & 73.7 & 457 & 34.6 \\
\hline & 40 to 59 & 112 & 25.3 & 331 & 74.7 & 443 & 33.5 \\
\hline & 60 to 91 & 32 & 14.1 & 195 & 85.9 & 227 & 17.2 \\
\hline \multirow[t]{3}{*}{ Marital status } & Not married & 149 & 26.3 & 417 & 73.7 & 566 & 42.8 \\
\hline & Married & 185 & 24.9 & 561 & 75.2 & 746 & 56.4 \\
\hline & NA & 2 & 20.0 & 8 & 80.0 & 10 & 0.8 \\
\hline \multirow[t]{3}{*}{ Occupation } & Inside & 68 & 19.7 & 277 & 80.3 & 345 & 26.1 \\
\hline & Outside & 252 & 27.0 & 680 & 73.0 & 932 & 70.5 \\
\hline & NA & 16 & 35.6 & 29 & 64.4 & 45 & 3.4 \\
\hline \multirow[t]{4}{*}{ Income (minimum salaries - MS) } & 0 to $2 \mathrm{MS}$ & 21 & 15.6 & 114 & 84.4 & 135 & 10.2 \\
\hline & 2 to $4 \mathrm{MS}$ & 221 & 25.1 & 660 & 74.9 & 881 & 66.7 \\
\hline & $4 \mathrm{MS}$ or more & 36 & 35.0 & 67 & 65.0 & 103 & 7.8 \\
\hline & NA & 58 & 28.6 & 145 & 71.4 & 203 & 15.3 \\
\hline \multirow[t]{4}{*}{ Schooling } & 7 years or less & 137 & 23.0 & 459 & 77.0 & 596 & 45.1 \\
\hline & 8 to 11 years & 144 & 27.8 & 437 & 75.2 & 581 & 43.9 \\
\hline & More than 12 years & 43 & 45.3 & 52 & 54.7 & 95 & 7.2 \\
\hline & NA & 12 & 24.0 & 38 & 76.0 & 50 & 3.8 \\
\hline \multirow[t]{2}{*}{ House type } & Apartment & 75 & 34.6 & 142 & 65.4 & 217 & 16.4 \\
\hline & House & 261 & 23.6 & 844 & 76.4 & 1105 & 83.6 \\
\hline \multirow[t]{3}{*}{ Home owership } & Owner & 222 & 25.6 & 646 & 74.4 & 868 & 65.7 \\
\hline & Non-owner & 109 & 24.7 & 332 & 75.3 & 441 & 33.3 \\
\hline & NA & 5 & 38.5 & 8 & 61.5 & 13 & 1.0 \\
\hline \multirow[t]{3}{*}{ Hours at home (per day) } & $12 \mathrm{~h}$ or less & 174 & 27.6 & 457 & 72.4 & 631 & 47.7 \\
\hline & More than $12 \mathrm{~h}$ & 155 & 23.3 & 510 & 76.7 & 665 & 50.3 \\
\hline & NA & 7 & 26.9 & 19 & 73.1 & 26 & 2.0 \\
\hline \multirow[t]{3}{*}{ Number of residents } & 4 or less & 268 & 26.1 & 759 & 73.9 & 1027 & 77.7 \\
\hline & More than 4 & 67 & 23.2 & 222 & 76.8 & 289 & 21.9 \\
\hline & NA & 1 & 16.7 & 5 & 83.3 & 6 & 0.4 \\
\hline
\end{tabular}

${ }^{\mathrm{a}}$ row percentages; ${ }^{\mathrm{b}}$ colum percentages

our final model presented narrower 95\%CI than the complete spatial model. For this model the house type had a CI95\% not including 0, while there was no evidence of an effect of age and race $(95 \% \mathrm{CI}$ including 0). Additional file 5 compares the results of the final model with the imputed covariate non-spatial model and the mean difference between them is that
Income lost their importance when the spatial component was considered.

\section{Discussion}

The high seroprevalence that we founded in our study reveals a large burden of disease of DENV in São José do Rio Preto. The seroprevalence found in people aged 
Table 2 Posterior mean fixed effects and 95\% credible intervals (Cl), presented as crude and adjusted odds ratios (OR), of the final model (intercept, covariates and the spatial component for the imputed datasets) (baseline category=1), Vila Toninho neighbourhood, São José do Rio Preto, state of São Paulo, Brazil, 2015-2016

\begin{tabular}{|c|c|c|c|c|c|c|c|}
\hline \multirow[t]{4}{*}{ Covariate } & \multirow[t]{4}{*}{ Categories } & \multicolumn{6}{|c|}{ Posterior mean fixed effects } \\
\hline & & \multicolumn{3}{|c|}{ Crude OR } & \multicolumn{3}{|c|}{ Adjusted OR } \\
\hline & & \multirow[t]{2}{*}{$\overline{O R}$} & \multicolumn{2}{|l|}{$95 \% \mathrm{Cl}$} & \multirow[t]{2}{*}{$\mathrm{OR}$} & \multicolumn{2}{|l|}{$95 \% \mathrm{Cl}$} \\
\hline & & & Lower & Upper & & Lower & Upper \\
\hline Intercept & & & & & 1.55 & 0.69 & 3.46 \\
\hline \multirow[t]{2}{*}{ Sex } & Male & 1 & & & 1 & & \\
\hline & Female & 0.99 & 0.76 & 1.29 & 0.96 & 0.73 & 1.27 \\
\hline \multirow[t]{2}{*}{ Race } & White & 1 & & & 1 & & \\
\hline & Non-white & 1.36 & 1.04 & 1.78 & 1.42 & 1.08 & 1.89 \\
\hline \multirow[t]{2}{*}{ Marital status } & Not married & 1 & & & 1 & & \\
\hline & Married & 1.16 & 0.89 & 1.51 & 0.93 & 0.70 & 1.25 \\
\hline Age (standardized) & & 1.39 & 1.21 & 1.60 & 1.43 & 1.21 & 1.70 \\
\hline \multirow[t]{2}{*}{ Schooling } & 7 years or less & 1 & & & 1 & & \\
\hline & More than 7 years & 0.80 & 0.61 & 1.03 & 1.01 & 0.76 & 1.35 \\
\hline \multirow[t]{2}{*}{ Occupation } & Internal area & 1 & & & 1 & & \\
\hline & External area & 0.70 & 0.51 & 0.96 & 0.91 & 0.63 & 1.31 \\
\hline Income (standardized) & & 0.89 & 0.78 & 1.01 & 0.89 & 0.78 & 1.02 \\
\hline \multirow[t]{2}{*}{ House type } & Apartment & 1 & & & 1 & & \\
\hline & House & 2.04 & 1.10 & 3.78 & 2.02 & 1.10 & 3.73 \\
\hline \multirow[t]{2}{*}{ Home ownership } & Owner & 1 & & & 1 & & \\
\hline & Non-owner & 0.91 & 0.69 & 1.21 & 0.97 & 0.72 & 1.31 \\
\hline \multirow[t]{2}{*}{ Hours at home (per day) } & $12 \mathrm{~h}$ or less & 1 & & & 1 & & \\
\hline & More than $12 \mathrm{~h}$ & 1.17 & 0.91 & 1.51 & 0.95 & 0.70 & 1.27 \\
\hline \multirow[t]{2}{*}{ Number of residents } & 4 or less & 1 & & & 1 & & \\
\hline & More than 4 & 1.13 & 0.82 & 1.55 & 1.33 & 0.95 & 1.86 \\
\hline
\end{tabular}

10-19 years, slightly lower than the seroprevalences for the other age groups, also reveals high rates of transmission in the recent past. These results can be seen as a consequence of events of the last five and four decades, respectively, in Brazil and the state of São Paulo.

The process of reinfestation of the country by $A e$. aegypti, after its eradication, began in the 1970s [47] and currently the vector is present in all its States. The first dengue epidemic, post-eradication, occurred in the state of Roraima in 1981 and 1982, with circulation of DENV-1 and DENV-4 [48], followed by the introduction of DENV-1 in Rio de Janeiro in 1986 and its dispersion across several regions of the country [47, 49].

DENV-2 and DENV-3 were also introduced in Rio de Janeiro, respectively in 1990 and 2000, and also dispersed throughout Brazil [47, 50, 51]. Finally, DENV-4 was detected in Manaus, state of Amazon, Northern region of the country in 2005 [52] and, like the other serotypes, dispersed throughout the territory. Simultaneous circulation of the four serotypes generated hyperendemecity and increasing incidences, with a peak in 2015 and occurrence of over 1.6 million cases, and an increase in the number of dengue deaths [53].

Ae. aegypti reinfestation in the state of São Paulo was detected in 1985 [54] and the first dengue epidemic occurred in 1990 and 1991, with the circulation of DENV-1 [21]. DENV-2, 3 and 4 were introduced respectively in 1998, 2002 [55] and 2011 [36]. Despite the infestation by the vector in Sao Paulo have been detected only in the 1980s and the first epidemic of dengue have occurred in the early 1990s, the state has had high incidences of dengue and deaths. Among the 1.6 million cases and 1.7 thousand deaths from dengue in Brazil in 2015, around 750 thousand cases and 660 deaths were registered in São Paulo [53].

The comparison of the seroprevalence found in São José do Rio Preto cannot be made with other regions of the State, since our bibliographic survey detected only three studies, all of them developed in the 1990s, with an epidemiological situation distinct from the current situation of the state of São Paulo. The first and second studies were developed after dengue epidemics in Ribeirão 


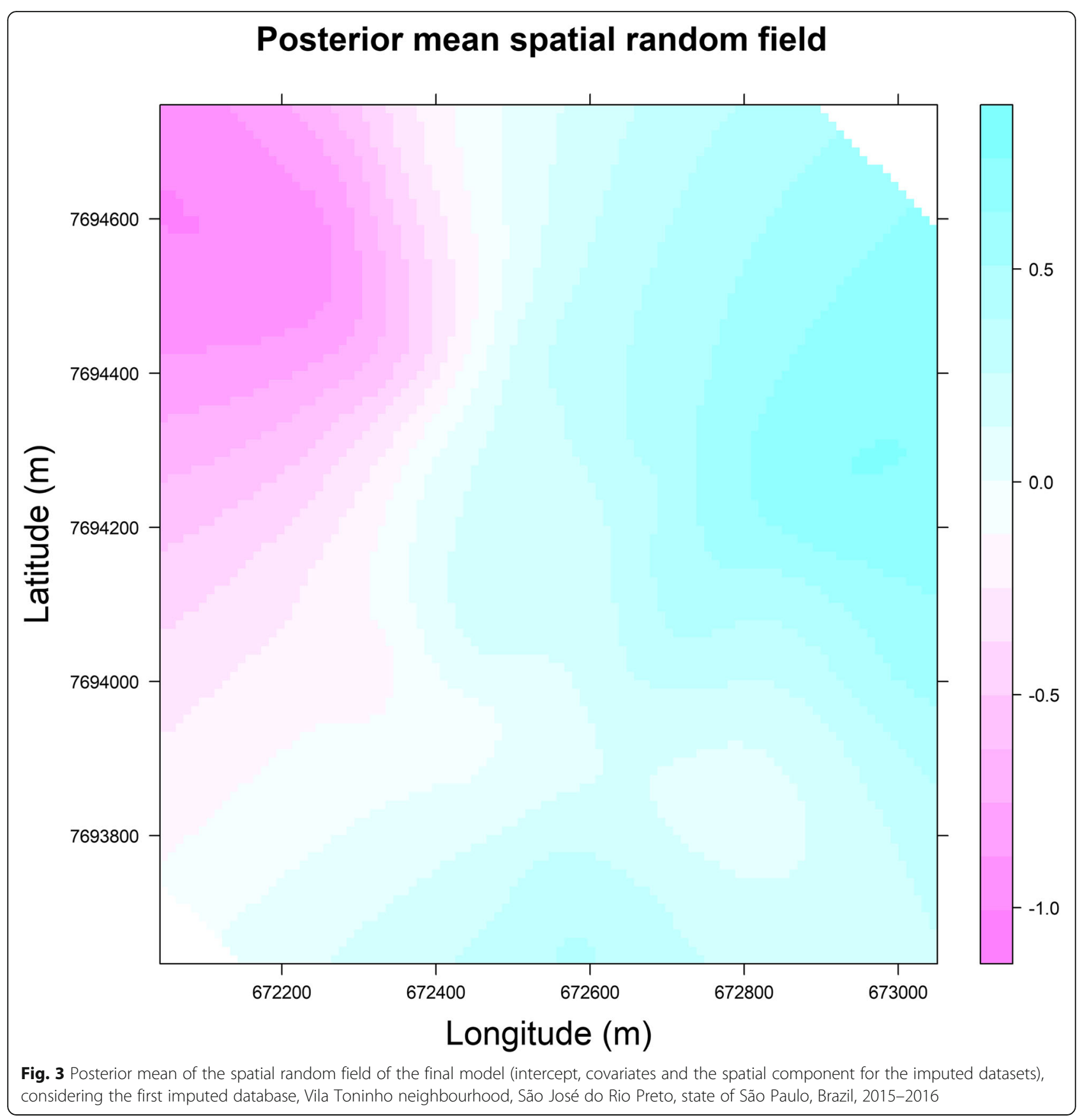

Preto (in 1992) and Santa Barbara D'Oeste (in 1995) and obtained seroprevalences, respectively, of 5.4\% [21] and $0.6 \%$ [22], respectively. The third one was developed in Campinas (in 1998) and obtained a seroprevalence of $14.8 \%$ [23].

On the other hand, the seroprevalence found in São José do Rio Preto is in line with the results of two studies carried out in the 2000s and one in the decade of 2010 in Brazilian capitals: between 74.3 and $91.1 \%$ in three areas of Recife, state of Pernambuco, between 2005 and 2006 in a population older than 5 years [30]; between 56.1 and $77.4 \%$ in three different districts of Rio de Janeiro, state of Rio de Janeiro, in 2007 in a population aged between 1 and 79 years [29]; and 75.7\% in Salvador, state of Bahia, between 2015 and 2016 in a population between 0 and 84 years old [34].

The seroprevalence found in São José do Rio Preto also is in line with the values found in studies developed in several Latin American [13, 17, 56-59] and Southeast Asian countries $[15,60]$.

The similarity between these results, both internal to Brazil as with Latin America and Southeast Asian countries, 


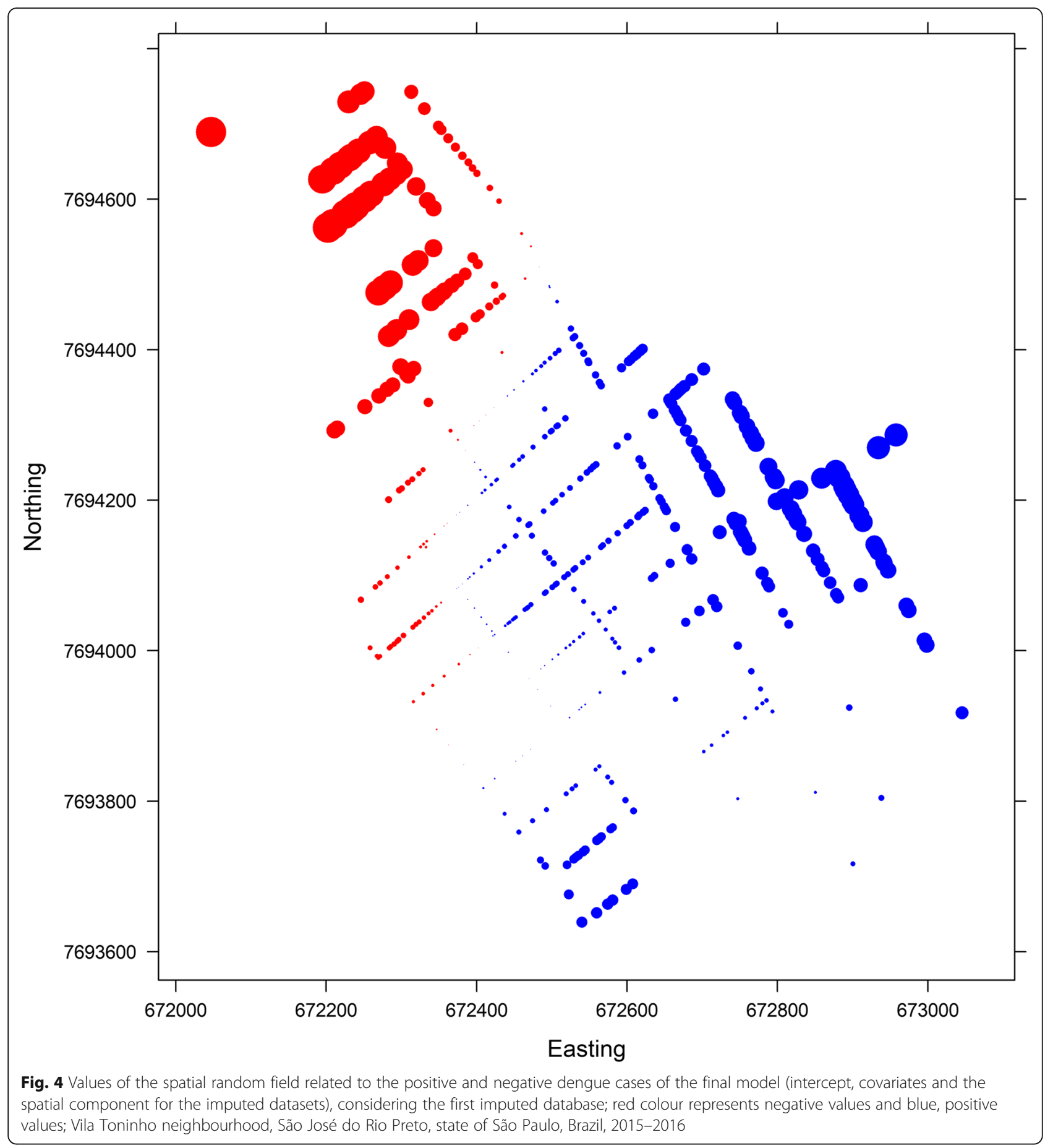

is related to similar epidemiological realities experienced by the localities considered, that is, a hyperendemic condition with simultaneous circulation of three or four DENV serotypes.

In addition to the high seroprevalence, the high proportion of people with no history of dengue but dengue seropositive in our study also is in line with other studies [11-13]. This confirms that seroepidemiological studies have advantages over those based on surveillance systems, especially because they detect asymptomatic infections [9, 14].

The positive association between age and a positive result for dengue confirms the results of several other studies $[11,15,26,29,30,57,58,61,62]$. The increase in seroprevalence with age is related to a longer period of exposure to the circulating DENV serotypes in endemic 
areas, that is, older people have had more time to be exposed than younger people [13, 30,57].

We did not detect an association between income, schooling and number of residents with seropositivity for dengue, variables that can be seen as representative of socioeconomic status. However, seroepidemiological studies [11, 26, 30,58] and incidence studies based on notification systems [63, 64] have identified a positive association between worse conditions. A hypothesis for the lack of association would be the low variability of these three variables in the study area: around $80 \%$ of the participants are characterised by income less than four minimum wages, around $80 \%$ of the cohort live in households with four or fewer people and a small proportion of people have reached a higher education.

Among the seroprevalence studies that we found in the scientific literature, none identified an association between race and seropositivity for dengue, and only one showed increased seroconversion in Afro-Colombians compared to whites [13]. Given the homogeneity of the variables representative of the socioeconomic level in the study area and that the non-whites were almost exclusively black and mixed individuals in our study, the fact they showed increased odds for seropositivity for dengue may be a reflection of the worse socioeconomic status of these people in Brazil. A study carried out in Brazil showed that black and mixed-race people presented a higher odds of a negative self-rated health than whites even after controlling for socioeconomic and demographic covariates [65].

Several studies have also found no association between sex and seroprevalence for dengue [13, 15, 26, 30, 59]. Only Amaya-Larios et al. [57] identified an increase in seroprevalence in men. However, they considered this an intriguing result and related it to cultural determinants of the communities, including the specific pattern of human movement of the sites surveyed.

The association between living arrangements (i.e. living in flats has lower risk for dengue) has been detected both in seroepidemiological studies [30, 31] and in incidence studies based on monitoring data [38]. The explanatory factors of this association would be related to less possibility of contact with the vector, since living in apartments means further away from Ae. aegypti breeding sites [30]. This affirmation is supported by a study developed in the same city of the present research to evaluate risk factors for vector household infestation. This study, in addition to identifying that the apartments were among the buildings with the lowest levels of infestation, showed that the presence of garden and yard (absent in the apartments) increased the risk of the presence of Ae. aegypti pupae [66].

The distance at which the spatial dependence was found occurring in Vila Toninho neighbourhood was higher than Ae. aegypti flight radius that usually does not exceed $200 \mathrm{~m}[67,68]$. This is in agreement with studies associating exposure to DENV, not only with vector-related viral dispersion, but also with human movements. Honorio et al. [29] identified that past exposure to dengue was associated with movement of people, as well as social and commercial activity. Liebman et al. [69] working with data on seroconversion and acute cases, found the cases agglomerated at distances up to $800 \mathrm{~m}$. Several authors have pointed out that human movement is an important factor to be considered in the spatial dimension of virus transmission and that this movement could be more important in viral dispersion than mosquitoes [14, 29, 69, 70].

The results of this study have public health implications, both in the evaluation of the strategies currently employed and in the definition of future strategies. They are also widely applicable, since the reality found in São José do Rio Preto should not be different from the reality of many medium and large Brazilian and Latin American cities. The high seroprevalence we found also points to the ineffectiveness of the control measures being adopted and the urgent need for their re-discussion [71]. On the one hand, high seroprevalence indicates risk of cases of severe dengue and deaths; on the other, as described in Kumar and Nielsen [17] and Netto et al. [34] this points to the fact that older people could even be close to their saturation point of immunity to multiple dengue serotypes. These are different situations that also need to be considered by the control services.

Finally, the rarity of seroepidemiological studies developed in Brazil should be discussed and reviewed. The development of this type of study should be encouraged, since they produce important information and knowledge to be used in structuring appropriate surveillance systems, effective control programs and in particular to define vaccination strategies.

One of the limitations of this study is the fact that its population was not a random sample of the study area's population but that people agreed to participate in the cohort study. This is related to the type of area chosen for its development. The fact that it was a relatively small and closed area (three of its frontiers are composed of forest, river and highway) was a matter of choice, which would facilitate the development of the work and the interpretation of the results, especially the entomological part of the study (untreated here). We also choose this area because its Basic Health Unit is linked to FAMERP, the educational institution that coordinates this research project, to serve as a foot hold for the development of the research. Even though the sample was not obtained randomly, this limitation is relieved by the fact that the households of the research participants present a distribution that covered almost all the blocks of the study area. Our sample also represented 
the internal distribution of households in most blocks of the study area. Only the blocks located at the southern end of the study area did not follow the spatial distribution described above.

Among the strengths of this study should be mentioned that this is one of the few carried out, despite its epidemiological importance. Another highlight is that the statistical model selected allowed the control of the spatial correlation between the individuals participating in the study so that the results obtained on the relationship between dengue seroprevalence and covariates were controlled by the geographical location of the individuals participating in the study. Moreover, the fact that the methodology we used took into account the geographical location of the participants and allowed the identification of the extent of the spatial dependence present in the study reaffirms the hypothesis that exposure to DENV is also linked with human movements.

\section{Conclusions}

The seropositive for dengue in the study area was equal to $74.6 \%$. Among the individuals who claimed that they never had dengue fever, 68.4\% (566/828) were dengue seropositive. Older people, of a non-white ethnicity and living in a house (instead of in an apartment), adjusted for the other socioeconomic and demographic covariates considered in our study, had higher risk of a positive serological result for dengue. Spatial dependence between observations occurred until $800 \mathrm{~m}$, even after adjustment for covariates, showing the necessity to consider the spatial component in the models. The use of INLA in a geostatistical approach in a Bayesian context allowed us to take into account the spatial dependence between the observations and identify the associated covariates to dengue seroprevalence.

\section{Additional files}

Additional file 1: Combination of the separate estimates obtained from the five imputed databases for the final model (intercept, covariates and the spatial component for the imputed datasets), Vila Toninho neighbourhood, São José do Rio Preto, state of São Paulo, Brazil, 2015-2016. (DOCX 15 kb)

Additional file 2: $R$ codes related to the analysis of the imputed data using R-INLA and a Bayesian Geostatistical approach. (R 123 kb)

Additional file 3: Deviance Information Criterion for the run models, Vila Toninho neighborhood, São José do Rio Preto, state of São Paulo, Brazil, 2015-2016. (DOCX 13 kb)

Additional file 4: Posterior means fixed effects and $95 \% \mathrm{Cl}$, in the logit scale (betas), of the final model (intercept, covariates and the spatial component for the imputed datasets) (Imp) and the non-imputed covariate spatial model (Not imp), Vila Toninho neighborhood, São José do Rio Preto, state of São Paulo, Br, 2015-2016. (PNG 240 kb)

Additional file 5: Posterior means fixed effects and $95 \% \mathrm{Cl}$, in the logit scale (betas), of the final model (intercept, covariates and the spatial component for the imputed datasets) (Spatial) and the imputed covariate non-spatial model (Non-spatial), Vila Toninho neighborhood, São José do Rio Preto, state of São Paulo, Brazil, 2015-2016. (PNG 229 kb)

\section{Abbreviations}

asl: above sea level; Cl: credible interval; DENV: dengue vírus; ELISA: Enzymelinked immunosorbent assay; FAMERP: School of Medicine of São José do Rio Preto; GF: Gaussian field; GMRF: Gaussian Markov random field; INLA: Integrated Nested Laplace Appromations; OR: Odds ratio; PC: penalized priors; SIRGAS: Sistema de Referência Geocêntrico para as Américas / em inglês Geocentric Reference System for the Americas; SPDE: Stochastic partial differential equation; UTM: Universal Transverse Mercator; VIF: variance inflation factor

\section{Acknowledgements}

We would like to thank to the League of Infectious Diseases of FAMERP.

\section{Funding}

This study was supported by the São Paulo Research Foundation (FAPESP) with grant numbers 2013/21719-3 and 2016/15012-1 for MLN, 2015/122950 for ACBT and 2017/09671-6 for FCN. It is also supported by the National Institute of Science and Technology in Dengue (INCT em Dengue). RAS was supported by the Coordination for the Improvement of Higher Education Personnel (CAPES) with grant. MLN and FCN are CNPq (National Council for Scientific and Technological Development) Research Fellows. The funding agencies did not play any role in the design of the study and collection, analysis, and interpretation of data and in writing the manuscript.

\section{Availability of data and materials}

The datasets generated and/or analysed during the current study are not publicly available due they have the geographical coordinates of the participants' houses, information that allows the identification of participants, which goes against what has been established in our Informed Consent Form. This formulary ensures for each participant that he/she will not be identified and that the confidential nature of the information related to his/her privacy will be kept. However, these datasets are available from the corresponding author on reasonable request.

\section{Authors' contributions}

FCN, MRD, EAF, ACBT and MLN designed this study. RAS, NZ, GCDS, MCPP, MRD, CFE, EAF, KRD, MTOM, GFG and ACBT participated in the field data collection. RAS and NZ performed the laboratory assays. RAS, NZ, GCDS and CFE provided support with data management. MCPP, MRD, EAF and MLN supervised the field data collection and the laboratory assays. FCN, RAS, NSS and MB performed the data analysis. MLN was the research coordinator. FCN, RAS, NSS, MB and MLN wrote the original draft of this study. All authors made the critical reading and contributed to the elaboration of the final version of this manuscript. All authors read and approved the final manuscript.

\section{Ethics approval and consent to participate}

This project was submitted to and approved by Ethics and Research Committee of FAMERP (CAAE 32293014.0.0000.5415). The residents aged 10 years or older of the study area were invited to participate of the study. The invitation was preceded by an explanation of the objectives, the duration of the study (4 years) and the need to answer questionnaires and perform annual blood collections. Residents of legal age (18years or older) who agreed to participate in the study signed an Informed Consent Form. For the people aged less than 18 years old, we asked for their agreement as well as for their parents', who signed the Informed Consent Form as their legal representatives.

\section{Consent for publication}

Not applicable.

\section{Competing interests}

The authors declare that they have no competing interests.

\section{Publisher's Note}

Springer Nature remains neutral with regard to jurisdictional claims in published maps and institutional affiliations.

\section{Author details}

${ }^{1}$ Departamento de Epidemiologia, Faculdade de Saúde Pública, Universidade de São Paulo (USP), Avenida Doutor Arnaldo 715, São Paulo, SP 01246-904, Brazil. 'Laboratório de Pesquisas em Virologia, Departamento de Doenças Dermatológicas Infecciosas e Parasitárias, Faculdade de Medicina de São José 
do Rio Preto (FAMERP), Avenida Brigadeiro Faria Lima, 5416, São José do Rio Preto, SP 15090-000, Brazil. ${ }^{3}$ Laboratório de Modelagens Matemática e Estatística em Medicina, Faculdade de Medicina, União das Faculdades dos Grandes Lagos, Rua Doutor Eduardo Nielsen 960, São José do Rio Preto, SP 15030-070, Brazil. “'Laboratório de Entomologia, Superintendência de Controle de Endemias, Rua Cardeal Arcoverde 2878, São Paulo, SP 05408-003, Brazil. ${ }^{5}$ MRC-PHE Centre for Environment and Health, Department of Epidemiology and Biostatistics, Imperial College, St. Mary's Campus, Norfolk Place, London W2 1PG, UK.

\section{Received: 26 February 2018 Accepted: 9 May 2019}

Published online: 20 May 2019

\section{References}

1. Gubler D. Dengue, urbanization and globalization: the unholy trinity of the 21st century. Trop Med Health. 2011;39(4):Suppl):3-11. https://doi.org/10. 2149/tmh.2011-S05.

2. Brady OJ, Gething PW, Bhatt S, Messina JP, Brownstein JS, Hoen AG, et al. Refining the global spatial limits of dengue virus transmission by evidencebased consensus. PLoS Negl Trop Dis. 2012;6(8):e1760. https://doi.org/10. 1371/journal.pntd.0001760.

3. Bhatt $S$, Gething PW, Brady OJ, Messina JP, Farlow AW, Moyes CL, et al. The global distribution and burden of dengue. Nature. 2013;496(7444):504-7. https://doi.org/10.1038/nature12060.

4. Guzman MG, Harris E. Dengue. Lancet. 2015;385(9966):453-65. https://doi. org/10.1016/S0140-6736(14)60572-9.

5. Vos T, Allen C, Arora M, Barber RM, Bhutta ZA, Brown A, et al. Global, regional, and national incidence, prevalence, and years lived with disability for 310 diseases and injuries, 1990-2015: a systematic analysis for the global burden of disease study 2015. Lancet. 2016;388:1545-602. https://doi.org/10. 1016/S0140-6736(16)31678-6.

6. Stanaway JD, Shepard DS, Undurraga EA, Halasa YA, Coffeng LE, Brady OJ, et al. The global burden of dengue: an analysis from the global burden of disease study 2013. Lancet Infect Dis. 2016;16(6):712-23 Doi.org/10.1016/ S1473-3099(16)00026-8.

7. Teixeira MG, Siqueira-Junior JB, Ferreira GLC, Bricks L, Joint $G$. Epidemiological trends of dengue disease in Brazil (2000-2010): a systematic literature search and analysis. PLoS Negl Trop Dis. 2013;7(12): e2520. https://doi.org/10.1371/journal.pntd.0002520.

8. Wijayanti SPM, Porphyre T, Chase-Topping M, Rainey SM, McFarlane M,

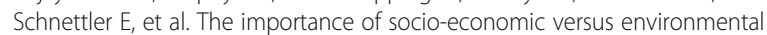
risk factors for reported dengue cases in Java, Indonesia. PLoS Negl Trop Dis. 2016;10(9):e0004964. https://doi.org/10.1371/journal.pntd.0004964.

9. Imai N, Dorigatti I, Cauchemez S, Ferguson NM. Estimating dengue transmission intensity from Sero-prevalence surveys in multiple countries. PLoS Negl Trop Dis. 2015;9:e0003719. https://doi.org/10.1371/journal.pntd. 0003719.

10. Yung CF, Chan SP, Thein TL, Chai SC, Leo YS. Epidemiological risk factors for adult dengue in Singapore: an 8-year nested test negative case control study. BMC Infec Dis. 2016;16:323. https://doi.org/10.1186/ s12879-016-1662-4.

11. Teixeira MG, Barreto ML, Costa MCN, Ferreira LDA, Vasconcelos PFC, Cairncross S. Dynamics of dengue virus circulation: a silent epidemic in a complex urban area. Tropical Med Int Health. 2002;7(9):757-62.

12. Rodriguez-Barraquer I, Cordeiro MT, Braga C, de Souza WV, Marques ET, Cummings DAT. From re-emergence to Hyperendemicity: the natural history of the dengue epidemic in Brazil. PLoS Negl Trop Dis. 2011;5(1):e935. https://doi.org/10.1371/journal.pntd.0000935.

13. Carabali M, Lim JK, Velez DC, Trujillo A, Egurrola J, Lee KS, et al. Denque virus serological prevalence and seroconversion rates in children and adults in Medellin, Colombia: implications for vaccine introduction. Ent J Infec Dis. 2017;58:27-36. https://doi.org/10.1016/j.jij.2017.02.016.

14. Vincenti-Gonzalez MF, Grillet ME, Velasco-Salas ZI, Lizarazo EF, Amarista MA, Sierra GM, et al. Spatial analysis of dengue Seroprevalence and modeling of transmission risk factors in a dengue Hyperendemic City of Venezuela. PLoS Negl Trop Dis. 2017;11(1):e0005317. https://doi.org/10. 1371/journal.pntd.0005317.

15. Vongpunsawad S, Intharasongkroh D, Thongmee T, Poovorawan Y (2017) Seroprevalence of antibodies to dengue and chikungunya viruses in Thailand. PLoS One 2017;12(6):e0180560. Doi: https://doi.org/10.1371/ journal.pone.0180560.
16. World Health Organization. Dengue vaccine: WHO position paper-July 2016. Geneva: WHO; 2016.

17. Kumar A, Nielsen AL. Trends in the patterns of IgM and IgG antibodies in febrile persons with suspected dengue in Barbados, an English-speaking Caribbean country, 2006-2013. J Infec Public Health. 2015;8:583-92. https://doi.org/10.1016/j.jiph.2015.05.013.

18. Vasconcelos PFC, Rosa EST, Rosa JFS, Freitas RB, Degallier N, Rodrigues SG, et al. Epidemia de fibre clássica de dengue causada pelo sorotipo $2 \mathrm{em}$ Araguaiana, Tocantins, Brasil. Rev Inst Med Trop Sao Paulo. 1993;35(2):141-8.

19. Vasconcelos PFC, Lima JWOL, Rosa APAT, Timbo MJ, Rosa EST, Lima HR, et al. Epidemia de dengue em Fortaleza, Ceará: inquérito soro-epidemiológico aleatório. Rev Saúde Pública. 1998;32(5):447-54.

20. Vasconcelos PFC, Lima JWOL, Raposo ML, Rodrigues SG, Rosa JFST, Amorim SMC, et al. Inquérito soro-epidemiológico na llha de São Luis durante epidemia de dengue no Maranhão. Rev Soc Bras Med Trop. 1999;32(2):171-9.

21. Figueiredo LTM, Owa MA, Carlucci RH, FAbbro AL, Mello NV, Capuano DM, et al. Encuesta serológica sobre el dengue en Ribeiráo Preto, Sáo Paulo, Brasil. Bol Oficina Sanit Panam. 1995;118(6):499-509.

22. Lima VCL, Figueiredo LTM, Correa HR, Leite OF, Rangel O, Vido AA, et al. Denque: inquérito sorológico pós-epidêmico em zona urbana do estado de São Paulo (Brasil). Rev Saúde Pública. 1999;33(6):566-74.

23. Lima VCL, Rangel O, Andrade VR, Silveira NYJ, Oliveira SS, Figueiredo LTM. Dengue: inquérito populacional para pesquisa de anticorpos e vigilância virológica no Município de Campinas, São Paulo, Brasil. Cad Saúde Pública. 2007;23(3):669-80

24. Teixeira MG, Morato V, Barreto FR, CMC M, Barreto ML, MCN C, et al. Risk factors for the incidence of dengue virus infection in preschool children. Tropical Med Int Health. 2012;17(11):1391-5. https://doi.org/10.1111/j.13653156.2012.03086.x.

25. Siqueira-Junior JB, Martelli CMT, Maciel IJ, Oliveira RM, Ribeiro MG, Amorim $F P$, et al. Household survey of dengtue infection in Central Brazil: spatial point pattern analysis and risk factors assessment. Am J Trop Med Hyg. 2004;71(5):646-51.

26. Siqueira-Junior JB, Maciel IJ, Barcellos C, Souza WV, Carvalho MS, Nascimento NE, et al. Spatial point analysis based on dengue surveys at household level in Central Brazil. BMC Public Health. 2008:8:361. https://doi. org/10.1186/1471-2458-8-361.

27. Cordeiro MT, Silva AM, Brito CAA, Nascimento EJM, Magalhães MCF, Guimarães GF, et al. Characterization of a dengue patient cohort in Recife, Brazil. Am J Trop Med Hyg. 2007;77:1128-34.

28. Silva-Nunes M, Souza VAF, Pannuti CS, Sperança MA, Terzian ACB, Nogueira ML, et al. Risk Factors for dengue virus infection in rural amazonia: population-based cross-sectional surveys. Am J Trop Med Hyg. 2008;79(4):485-94.

29. Honorio NA, Nogueira RM, Codeço CT, Carvalho MS, Cruz OG, Magalhães MAFM, et al. Spatial evaluation and modeling of dengue Seroprevalence and vector density in Rio de Janeiro, Brazil. PLoS Negl Trop Dis. 2009;3(11): e545. https://doi.org/10.1371/journal.pntd.0000545.

30. Braga C, Luna CF, Martelli CMT, Souza WV, Cordeiro MT, Alexander N, et al. Seroprevalence and risk factors for dengue infection in socioeconomically distinct areas of Recife, Brazil. Acta Trop. 2010;113(3):234-40. https://doi.org/ 10.1016/j.actatropica.2009.10.021.

31. Pessanha JEM, Caiaffa WT, Kroon EG, Proietti FA. Dengue em três distritos sanitários de Belo Horizonte, Brasil: inquérito soroepidemiológico de base populacional, 2006 a 2007. Rev Panam Salud Publica. 2010;27(4):252-8.

32. Martins AC, Pereira TM, Oliart-Guzman H, Delfino BM, Mantovani SAS, Braña AM, et al. Seroprevalence and seroconversion of dengue and implications for clinical diagnosis in Amazonian children. Inter Persp Infect Dis. 2014; 703875. https://doi.org/10.1155/2014/703875.

33. Castanha PMS, Montarroyos UR, Silveira MM, Albuquerque GDM, Mello MJG, Lopes KGS, et al. Incidence and risk factors for dengue virus (DENV) infection in the first 2 years of life in a Brazilian prospective birth cohort. Epidemiol Infect. 2017;145:2971-9. https://doi.org/10.1017/ S095026881700214X.

34. Netto EM, Moreira-Soto A, Pedroso C, Höser C, Funk S, Kucharski AJ, et al. High Zika virus seroprevalence in Salvador, northeastern Brazil limits the potential for further outbreaks. mBio 2017;8:e01390-e01317. Doi: https://doi. org/10.1128/mBio.01390-17.

35. Mondini A, Bronzoni RVM, Nunes SH, Chiaravalloti Neto F, Massad E, Alonso WJ, et al. Spatio-temporal tracking and phylodynamics of an urban dengue 
3 outbreak in São Paulo, Brazil. PLoS Negl Trop Dis. 2009;3:e488. https://doi. org/10.1371/journal.pntd.0000448.

36. Rocco IM, Silveira VR, Maeda AY, Silva SJS, Spenassatto C, Bisordi I, et al. First isolation of dengue 4 in the state of São Paulo, Brazil, 2011. Rev Inst Med Trop Sao Paulo. 2012;54(1):49-51. https://doi.org/10.1590/S003646652012000100009 .

37. Costa AIP, Natal D. Distribuição espacial da dengue e determinantes socioeconômicos em localidade urbana no Sudeste do Brasil. Rev Saude Publica. 1998;32(3):232-6.

38. Mondini A, Chiaravalloti-Neto F. Spatial correlation of incidence of dengue with socioeconomic, demographic and environmental variables in a Brazilian city. Sci Total Environ. 2008;393(2-3):241-8. https://doi.org/10.1016/ j.scitotenv.2008.01.010

39. Zuur AF, leno EN, Elphick CS. A protocol for data exploration to avoid common statistical problems. Methods Ecol Evol. 2010;1:3-14. https://doi. org/10.1111/j.2041-210X.2009.00001.X.

40. Buuren S, Groothuis-Oudshoorn K. Mice: multivariate imputation by chained equation in R. J Stat Softw. 2011;45(3):1-67.

41. R Core Team 2017. R: A Language and Environment for Statistical Computing, Vienna, Austria. 2017. https://www.r-project.org/. Accessed 5 June 2017.

42. Cressie N. Statistics for spatial data. New York: Wiley; 1993.

43. Rue H, Martino S, Chopin N. Approximate Bayesian inference for latent Gaussian models by using integrated nested Laplace approximations. J Roy Stat Soc B. 2009;71(2):319-92. https://doi.org/10.1111/j.1467-9868. 2008.00700.x.

44. Rubin DB. Multiple imputation for nonresponse in surveys. New York: John Wiley \& Sons; 1987.

45. Blangiardo M, Cameletti M. Spatial and Spatio-temporal Bayesian models with R-INLA. Chichester: John Wiley and Sons; 2015.

46. Simpson DP, Rue H, Martins TG, Riebler A, Sorbye SH. Penalising model component complexity: a principled, practical approach to constructing priors. Stat Sci. 2017;32(1):1-28. https://doi.org/10.1214/16-STS576.

47. Dick OB, Martin JLS, Montoya RH, Diego J, Zambrano B, Dayan G. Review: The history of dengue outbreaks in the Americas. Am J Trop Med Hyg. 2012:87(4):584-93. https://doi.org/10.4269/ajtmh.2012.11-0770.

48. Osanai CH, Travassos da Rosa AP, Tang AT, do Amaral AS, Passos AD, Tauil PL. Outbreak of dengue in Boa Vista, Roraima: preliminary report. Rev Inst Med Trop Sao Paulo. 1983;25:53-4.

49. Schatzmayr HG, Nogueira RMR, Travassos Da Rosa APA (1986) An outbreak of dengue virus at Rio de Janeiro. Mem Inst Oswaldo Cruz 1986; 81: 245-246.

50. Nogueira RMR, Miagostovich MP, Lampe E, Schatzmayr HG. Isolation of dengue virus type 2 in Rio de Janeiro. Mem Inst Oswaldo Cruz. 1990;85:253.

51. Nogueira RMR, Miagostovich MP, Filippis AMB, Pereira MAS, Schatzmayr HG. Dengue virus type 3 in Rio de Janeiro, Brazil. Mem Inst Oswaldo Cruz. 2001;96:925-6.

52. Figueiredo RMP, Naveca FG, Bastos MS, Melo MN, Viana SS, Gomes MP, et al. Dengue vírus Type 4, Manaus, Brazil. Emerg Infec Dis. 2008;14(4):667-9.

53. Brasil. Ministério da Saúde. Boletim Epidemiológico - Monitoramento dos casos de dengue, febre de chikungunya e febre pelo vírus Zika até a Semana Epidemiológica 51, 2016. 2017. http://portalarquivos.saude.gov.br/ images/pdf/2017/janeiro/12/2017_001-Dengue SE51_publicacao.pdf. Accessed 2 Feb 2018.

54. Chiaravalloti-Neto. Descrição da colonização de Aedes aegypti na região de São José do Rio Preto, São Paulo. Rev Soc Bras Med Trop. 1997;30(4):279-85.

55. Santos CLS, Sallum MAM, Foster PG, Rocco IM. Molecular analysis of the dengue virus type 1 and 2 in Brazil based on sequences of the genomic envelope-nonstructural protein 1 junction region. Rev Inst Med Trop Sao Paulo. 2004;46:145-52

56. Morrison AC, Minnick SL, Rocha C, Forshey BM, Stoddard ST, Getis A, et al. Epidemiology of dengue virus in Iquitos, Peru 1999 to 2005: Interepidemic and epidemic patterns of transmission. PLoS Negl Trop Dis. 2010;4(5):e670, https://doi.org/10.1371/journal.pntd.0000670

57. Amaya-Larios IY, Martinez-Vega RA, Mayer SV, Galeana-Hernández M, Comas-Garcia A, Sepulveda-Salinas KJ, et al. Seroprevalence of neutralizing antibodies against dengue virus in two localities in the state of Morelos, Mexico. Am J Trop Med Hyg. 2014;91(5):1057-65. https://doi.org/10.4269/ ajtmh.14-0145

58. Velasco-Salas ZI, Sierra GM, Guzman DM, Sambrano J, Vivas D, Comach G, et al. Dengue Seroprevalence and risk factors for past and recent viral transmission in Venezuela: a comprehensive community-based study. Am J Trop Med Hyg. 2014;91(5):1039-48. https://doi.org/10.4269/ajtmh.14-0127.

59. Weppelmann TA, Dume A, Fricken ME, Elbadry AM, Rochars MDB, Boncy J, et al. A tale of two Flaviviruses: a Seroepidemiological study of dengue virus and West Nile virus transmission in the Ouest and Sud-Est departments of Haiti. Am J Trop Med Hyg. 2017;96(1):135-40. https:// doi.org/10.4269/ajtmh.16-0422.

60. Prayitno A, Taurel AF, Nealon J, Satari HI, Karyanti MR, Sekartini R, et al. Dengue seroprevalence and force of primary infection in a representative population of urban dwelling Indonesian children. PLoS Negl Trop Dis. 2017:11(6):e0005621. https://doi.org/10.1371/journal.pntd.0005621.

61. Pereira Y, Samudio M, Ojeda A, Cabello A. Seroprevalencia de la infección por dengue en un distrito del Chaco Paraguayo. Estudio poblacional. Rev Chil Infectol. 2015;32(6):618-27.

62. Dhar-Chowdhury P, Paul KK, Haque CE, Hossain S, Lindsay LR, Dibernardo A, et al. Dengue seroprevalence, seroconversion and risk factors in Dhaka, Bangladesh. PLoS Negl Trop Dis. 2017;11(3):e0005475. https://doi.org/10, 1371/journal.pntd.0005475.

63. Teurlai M, Menkès $C E$, Cavarero V, Degallier N, Descloux E, Grangeon JP, et al., 2015. Socio-economic and climate factors associated with dengue fever spatial heterogeneity: a worked example in New Caledonia. PLoS Negl Trop Dis 2015;9 (12):e0004211. Doi: https://doi.org/10.1371/journal. pntd.0004211.

64. Farinelli EC, Baquero OS, Stepham C, Chiaravalloti-Neto F. Low socioeconomic condition and the risk of dengue fever: a direct relationship. Acta Trop. 2018. https://doi.org/10.1016/.actatropica.2018.01.005.

65. Chiaveggato-Filho LR. Disparidades étnico-raciais em saúde autoavaliada: análise multinível de 2.697 indivíduos residentes em 145 municípios brasileiros. Cad Saude Publica. 2013;29(8):1572-82.

66. Favaro EA, Dibo MR, Pereira M, Chierotti AP, Rodrigues-Junior AL, Chiaravalloti-Neto F. Aedes aegypti entomological indices in an endemic area for dengue in Sao Paulo State, Brazil. Doi: https://doi.org/10.1590/ S0034-8910.2013047004506.

67. Reiter P, Amador MA, Anderson RA, Clark GG. Dispersal of Aedes aegypti in an urban area after blood feeding as demonstrated by rubidium-marked eggs. Am J Trop Med Hyg. 1995;52(2):177-9.

68. Forattini OP. Culicidologia médica: identificação, biologia, epidemiologia, vol. 2. São Paulo: Edusp 2002.

69. Liebman KA, Stoddard ST, Morrison AC, Rocha C, Minnick S, Sihuincha M, et al. Spatial dimensions of dengue virus transmission across Interepidemic and epidemic periods in Iquitos, Peru (1999-2003). PLoS Negl Trop Dis. 2012;6(2):e1472. https://doi.org/10.1371/journal.pntd.0001472.

70. Harrington LC, Scott TW, Lerdthusnee K, Coleman RC, Costero A, Clark GG, et al. Dispersal of the dengue vector Aedes aegypti within and between rural communities. Am J Trop Med Hyg. 2005;72:209-20.

71. Achee NL, Gould F, Perkins TA, Reiner-Jr RC, Morrison AC, Ritchie SA, et al. A critical assessment of vector control for dengue prevention. PLoS Negl Trop Dis. 2015;9:e0003655. https://doi.org/10.1371/journal.pntd.0003655.

Ready to submit your research? Choose BMC and benefit from:

- fast, convenient online submission

- thorough peer review by experienced researchers in your field

- rapid publication on acceptance

- support for research data, including large and complex data types

- gold Open Access which fosters wider collaboration and increased citations

- maximum visibility for your research: over $100 \mathrm{M}$ website views per year

At $\mathrm{BMC}$, research is always in progress.

Learn more biomedcentral.com/submissions 